\title{
Interactions in Professional Discourses in Job Interviews: The Use of Interpersonal Meaning, Mood and Modality
}

Isai Amutan Krishnan, Sridewi Sriniwass

To Link this Article: http://dx.doi.org/10.6007/IJARBSS/v12-i1/12280

DOI:10.6007/IJARBSS/v12-i1/12280

Received: 16 November 2021, Revised: 18 December 2021, Accepted: 03 January 2022

Published Online: 25 January 2022

In-Text Citation: (Krishnan \& Sriniwass, 2022)

To Cite this Article: Krishnan, I. A., \& Sriniwass, S. (2022). Interactions in Professional Discourses in Job Interviews: The Use of Interpersonal Meaning, Mood and Modality. International Journal of Academic Research in Business and Social Sciences, 12(1), 2057- 2077.

\section{Copyright: @ 2022 The Author(s)}

Published by Human Resource Management Academic Research Society (www.hrmars.com)

This article is published under the Creative Commons Attribution (CC BY 4.0) license. Anyone may reproduce, distribute, translate and create derivative works of this article (for both commercial and non0-commercial purposes), subject to full attribution to the original publication and authors. The full terms of this license may be seen at: http://creativecommons.org/licences/by/4.0/legalcode

Vol. 12, No. 1, 2022, Pg. 2057- 2077

Full Terms \& Conditions of access and use can be found at http://hrmars.com/index.php/pages/detail/publication-ethics 


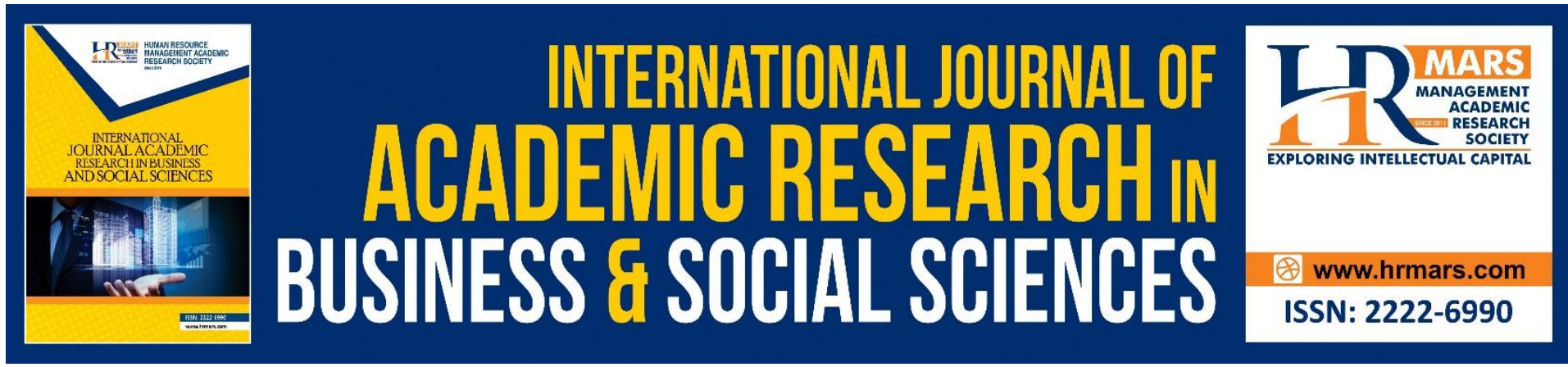

\title{
Interactions in Professional Discourses in Job Interviews: The Use of Interpersonal Meaning, Mood and Modality
}

\author{
Isai Amutan Krishnan \\ School of Liberal Arts and Science and Technology \\ Email: isai.amutan@perdanauniversity.edu.my, amuthan.isai@gmail.com \\ Sridewi Sriniwass \\ University of Malaya Faculty of Languages and Linguistics, Perdana University \\ Email: sridevi@um.edu.my
}

\begin{abstract}
This paper presents an aspect of the investigation into the interaction in professional discourse,that focuses on interpersonal meanings in a job interview. The theory of the interpersonal metafunction or the clause as exchange from systematic functional linguistics is used to analyse the interactions between interviewers and interviewees in job interviews. The study uses Mood and Modality to examine closely how interaction is carried out in the interviews. In an interview, the interviewer uses particular speech roles and the interviewee responds accordingly. However, the current study shows a variety of responses that do not always complement the interviewer's speech role. Data for the study were obtained from 10 interviews from one interview session for the post of customer services. A qualitative content analysis was carried out using Halliday's Systematic Functional Linguistic theory on the clause as exchange that was deemed suitable to bring out the various meanings in the interviews. A close examination of Mood and Modality was carried out on the recurrent themes in the interviews such as strengths and weaknesses, problem solving strategies and initiative and working experiences of the interviewees. The findings show that recent Malaysian graduates have used mostly "can"at $28 \%$ and "will" at $35 \%$ as Modality resources. A study on the grammatical realisation of interaction in interviews is necessary for recruitment companies, human resources personnel and interviewees themselves. The current study hopes to contribute towards an understanding of current market demands for hiring employees in terms of interviews.
\end{abstract}

Keywords: Interaction, Interpersonal Meanings, Metafunction, Mood and Modality, Job Interviews, Systemic Functional Linguistics

\section{Introduction}

This study focuses on the investigation of interaction in professional discourse.It attempts to analyse how interaction is conducted during a job interview. especially on interpersonal meanings in terms of mood and modality. Interpersonal Meanings of Mood and Modality play 
an important role in the job interview to perceive the perception of interviewee. This shows that each spoken text has a relationship between the interviewer and interviewee to portray a good command of the English language which would undoubtedly create better understanding. Mood and Modality play an important role in professional discourse in job interviews.

Successful employment of human capital has been clearly recognised as the major contributor for effectiveness in organisations. Therefore, it is necessary that skilled employees, who can feel, think and behave effectively, are placed in organisations in order to enhance their organisational performance (Ahmed \& Farouk, 2008). A regular complaint is that many graduates do not meet the required minimum English proficiency level (Wai, 2011; Al-Atabi, 2019).Wai and Al-Atabi reported that in order to get a job, English language proficiency is essential. Newgraduates or graduates with a few years of experience demanded unrealistic salaries and benefits, but did not demonstrate sufficientabilitytoexpressthemselves during interviews. This could be one of the reasons many employers are reluctant to employ candidates as they have poor command of the English language and lack the ability to presente themselves during interviews (David, 2009; Abu Bakar, 2020; Chau, 2021). Thus, employers look for employees who have excellent soft skills, and are able to communicate and impress the interviewer (Pauw, 2006) and (Kenayathulla, 2021).

Therefore, the aim of the study is to investigate how interpersonal meanings in terms of Mood and Modality are exchanged to a successful interaction which creates a favourable impression effectively. This deals with the balanced momentum of interaction in professional discourse as in job interviews.

\section{Literature Review \\ Professional Discourse}

Professional discourse concerns interaction with other members in an institution such as a workplace, in business conversations, at medical and health care, in legal practices, in the mass media and job interviews. Goodwin (2004) describes professional discourse as communication which has to be expressed clearly to examine a person's comprehensive knowledge in a specific field (Goodwin, 2004). Bhatia (2004) notes that professional discourse is an intellectual communication between the interviewer and potential recruits and it is a situation where certain terms and words with specific meanings may be used.

Schryer and Spoel (2005, p.249) observe that Professional discourse explores "the two-fold relationship between discourse and context, outlining how professional discourse is continuously reconstructed" in relation to "changing contextual environments in professional conversations."

Holmes (2009) notes that professional discourse may be seen as a conversation in a variety of situations where it is common to agree or disagree in matters that arise especially in meetings. Professional discourse can also be carried out in humour to sustain the attention of the members in a meeting. She emphasises that it is necessary to create a humourous atmosphere in a meeting especially when the meeting takes hours.

Sarangi (2010) observes that professional discourse accesses a person's ability or expertise in a particular field. A person's knowledge in the area of interest can be identified via professional discourse.

Research on professional discourse though provides insights into the conditions and consequences of professional discourse. There is a need for continued research and 
application if it relates to the person's aptitude on how he or she carries himself or herself and should show how it is linguistically expressed to each other and allows the person the access to universal professional practice.

The views above are expressed based on studies conducted in professional discourses in an institution such as workplaces, in business conversations, at medical and health care centers, in legal practices, in the mass media and job interviews. However, these scholars have discussed the way in which the professional discourse is used in the daily lives and its influence on people.

\section{Interpersonal Meanings}

From the Systemic Functional Linguistic point of view, Mood and Modality are interpersonal resources which refer to how speakers and writers take up a position, express an opinion or point of view and make a judgment (Halliday, 1994). The views on Interpersonal Meanings show that certain expressions are used to mean anything and are allowed to have more than one meaning (Halliday, 1985). Halliday (1994) notes that there is more than one meaning at a time with the use of Interpersonal resources. He also notes that Interpersonal Meanings focus on the interactivity of the language either in spoken or written texts.

Interpersonal Meanings show two aspects of speech which are "extra-vocalisation and intra-vocalisation" (Martin, 2001, p.57). Eggins (2004, p20) observes from a semantic perspective that interpersonal meanings are "grammar resources of interaction". Droga and Humphrey (2002, p.117) observe that Interpersonal Meanings are methods of interactivity among various people as they converse or do not converse with each other.

These Interpersonal Meanings may be expressed through a number of grammatical resources. The grammatical resources of Mood and Modality consist of Modal Finites, Mood Adjunct and Metaphors of Modality (Halliday, 1994). In social interactions, the spoken exchanges are carried out through the direction of two clauses which are: the Subject and the Finite, which make up the mood of the clause. The remaining of the clause is the residue, which, in turn, has these constituents: Predicator, Complement, and Adjunct (Droga \& Humphrey, 2002).Although modality is not considered to be subjected to tense distinctions, it is said to combine freely with any tense. This is particularly obvious when modality is expressed by a modal adverb such as certainly, obviously, and usually as against a modal auxiliary such as can, could, have and has (Halliday, 1994). Therefore, how an interviewee communicates by relating his or her mind to the circumstances through the use of various modalities is examined in this study.

Modality can be expressed through modal verbal operators, mood adjuncts and metaphors of modality. By examining the speakers' degree of certainty through their use of modality as to whether they are open to doubt or are pressurised by another others. This study attempts to show how the job interview candidate applies his responsibility and viewpoint in an objective way. As such the importance of Interpersonal Meanings in job interviews cannot be overlooked.

According to Halliday (1994), the system of modality expresses the speaker's assessment of probabilities. The mood is one of the two verbal categories that involves expression on Modality. Common modal systems would be modal auxiliary verbs and verb inflections in imperative and subjunctive moods. At "the layer of the mood system, the clause is analysed for its potential to make possible the exchanges or interactions in which the human beings get themselves involved in society", which is what the interpersonal metafunction stands for (Halliday 1985; 1994, p.127). 
Depraetere and Reed (2006, p.3) conducted a study on Mood and Modality to find out how speakers focus on ability in terms of speech constructions. It was found that the speech method to determine the truth of questioning, stressed "polysemy" which is at least in a sense the distinction between "root and epistemic meanings" of a given modal, This is important in speech or utterances that represent the situation as facts and also indicated the notion of speech.

Jensen (2007, p.4) conducted a study on Mood and Modality that involve the expression of "factuality" and "non-factuality" by using Kim and Fesenmaier's (2008) theory. Jensen found that it was quite "dubious to include permission under the heading of obligation". "Optatives and maledictives", as well as other types of word choice also fall under this type of modality, although they have nothing to do with such likelihood. Nevertheless, Jensen found that the terms "epistemic" and "deontic" used by the participants used the connotations of English words as they have been widely used.Jensen also analyses the differences between the selected sentences in terms of factuality or reality and nonfactuality or unreality in small groups of two or three. Jenson found that the speaker's modality reflected on situations and specifically how it expressed the speakers' conception on likelihood or obligation

Vazquez and Diana (2008) conducted a study on epistemic modality markers to reveal the use of hedges in research articles in different disciplines like Marketing, Biology and Mechanical Engineering. This study was done based on computer readable data and the combination of mix-mode methods. It was found that each discipline tried to fulfil its social needs in different areas, which formed the discourse in the research article/ that focused on the written work.

Many studies have been conducted on speeches and political addresses that analysed on Interpersonal Meanings in terms of Mood and Modality. Olga (2009) conducted a study on diplomatic addresses, Perdana and Saragih (2009) conducted a study on Interpersonal Metaphor Texts on Najwa's talk, Ruijuan (2010) conducted a study on Interpersonal Meaning in Public Speech by Obama, Cai-Yan (2011) conducted a study on Interpersonal Functions of Metaphors of Modality of President Obama's 30 radio addresses, Shayegh's (2012) conducted a study on Modality in Political Discourses on Barak Obama and Martin Luther King's speeches and Nezhad and Tavakoli (2013) conducted a study on the use of Polarity and Mood Adjuncts.

There were also local researches conducted on written discourse. Wong(2009) conducted a study on two pairs of help-seeking and help-providing texts in the Interpersonal aspect and Tan (2010) conducted a study on Interpersonal Metaphors in Computer Science Text and Popular book text. Their reviews are as c follows:

Olga (2009) conducted a study on Interpersonal Meanings in the Genre of Diplomatic Addresses. Olga used Brown and Levinson's (1987) theory to analyse politeness strategy, Halliday's (1985) theory to analyse the interpersonal component of language and Swales's (1990) theory to analyse rhetorical structure. The speeches were presented by leaders of the United Nations Educational, Scientific and Cultural Organisation (UNESCO) from Japan, Senegal and Spain. They were Koichiro Matsura, Amadou-Mahtar M'Bow and Federico Mayor Zaragoza respectively. It was found that the speakers' conversation functions tended to be both negative and positive. Politeness strategies were related to show their respect and create a common ground. The conversation can be sensitive or exploited based on the method of speech. The Mood and Modality resources of speech show that the characteristics of the speaker towards his intentions may be shown through speech. 
The reviews below are on Systemic Functional Linguistics (SFL) in Interpersonal Metaphors on political discourse. Perdana and Saragih (2009) conducted a study on Interpersonal Metaphors in texts that were featured in Malta Najwa's talk show entitled 'Sang Penantang' and 'SengatanDahlan' on television programme. Three research aspects were raised: 1) Types of grammatical metaphors used in the talk shows; 2) The ways interpersonal metaphors were coded in the talk shows and 3) The ways contexts of the interpersonal metaphors were coded in the talk shows. It was found that most of the occurrences were on the metaphor of mood in Sang Penantang (94.85\%) and metaphor of modality was used less (5.14\%) In Sengatan Dahlan, metaphor of mood was (95.34\%) and metaphor of modality was $(4.65 \%)$. It was found that the metaphor of mood use was dominant because in this political talk show opinions and interpretations were expressed by speakers. Jian (2009) conducted a study on Interpreting Metaphor of Modality in advertising in English based on the modality system and the metaphor of modality. It was found that the metaphor of modality, a usual method to scheme modality and allocate modal responsibility plays the pragmatic role of foregrounding subjectivity and objectivity as well as expressing politeness. Hence, Jian's study would help advertisers to establish interpersonal relationships with the readers and to achieve their commercial goals by manipulating them. Wong (2009) conducted a study on two pairs of help-seeking and help-providing texts. Her study focuses on how interpersonal meanings are expressed by mood choice and modality used in the text and subsequently compares the texts from the interpersonal perspective to ascertain the features which may mark them as being "help-seeking" or "help-providing". The choice of mood and modality reflected the helper's efforts in upholding the role as a professional help-provider while maintaining a proper tone. The two help-seeking texts have a very high use of Declaratives (92.3\% \& 92.86\%) indicating the emphasis on providing information. The two help-providing texts (3.85\% \& $3.5 \%$ ) indicated that emphasises on providing instructions to solve problems. The insights gained from the study can aid in interpreting and expressing interpersonal meanings and hence sharpen their language skills to achieve the intended communicative goals.

There was another study conducted by Ruijuan (2010) on interpersonal meaning in Obama's public speech. This study explored how interpersonal meaning is achieved from the perspective of SFL with a focus on mood, modal auxiliary, personal pronouns and tense shift. Obama's speech showed that he used different modal auxiliaries to communicate with the people and a very creative manner of information was provided. It was found that Obama's frequent usage of "we," established an intimate relationship with the people. His language achieved certain interpersonal meanings during his speech

Similar to Ruijuan's (2010) study, Cai-Yan (2011) conducted a study on President Obama's speech. This time it was on 30 radio addresses analysing the interpersonal functions of metaphors of modality. Cai Yan investigated the extent ESL learners could understand the speeches. Obama's speech illustrated the imporance of metaphors of modality in realising his political purposes such as the representation of a good image, the confidence and the willingness to take responsibility and cautiousness in uncertainty. The findings show that the ESL learners were able to understand the radio addresses of Obama to comprehend his view points and could image his attitudes based on his addresses. These studies have contributed to the teaching of advanced listening, speaking and writing skills and they can develop communicative competence more effectively.

Tan (2010) conducted a study on Interpersonal Metaphors in text by investigating how interpersonal meanings are expressed by features of lixcogrammar and also focused on how 
they affects the interactiviness of text. The data examined consisted of two chapters each from different genres. The first was a chapter from a Computer Science text book and the second was a chapter from a popular text book. Both chapters were taken from the topic Loops. The analysis involved two systems, the Metaphor of Mood and Metaphor of Modality. It was found that the interpersonal metaphor was present when sentences had the potential of having additional layers of meaning. This study also attempted to show the distribution of interpersonal Metaphors and level of interactiviness of the text Computer Science compared to popular text book.

Shayegh (2012) conducted a study on Barak Obama and Martin Luther King's speeches. Shayegh attempted to have a precise look on modality in the political discourses of Barak Obama and Martin Luther King based on the critical perspective of Norman Fairclough (1985). Seven different speeches of Barak Obama were taken from websites and compared to "Beyond Vietnam - A Time to Break Silence," a speech by Martin Luther King to show how modality was manifested in their speeches. It was found that both Barak Obama and Martin Luther King used 'WILL' the most number of times in their speeches.

A study conducted by Nezhad and Tavakoli (2013) to investigate the use of Polarity and Mood Adjuncts between Persian and English conversations found the polarity of Persian mood adjuncts. Positive and negative discourses had been identified as an added marker on Mood adjuncts which had been used by these two languages such as 'not' ,'never' , 'hardly' in relation to positive forms. It was found that a severe negative message in context used the negative polarity mood adjuncts in Persian language was ascertained first by speakers in order to make the purpose clear. The findings also indicated that the use of a negative marker preceding the verb was essential for the speaker of Persian language in order to convey the correct negative messages.

Syamsidar, Ika and Dian (2019) conducted a study on the interpersonal meaning of Soekarno's speech. It was found that declarative clauses were predominantly used which demonstrated the speaker's language ability in delivering informative information in a persuasive speech. The finding further revealed that the speaker could create a close attention by using low modality to inspire the audience and built the confidence. There was another study conducted by Diah, Martin, Noer and Mustafa (2020) on the Mood and Modality influencing of ideology on news-Indonesia in BBC into interpersonal characteristics. It was reported that the texts have conveyed ideology meaning by using interpersonal characteristics. Further, Yang (2021) studied on the modality system in Chinese perspectives. It was reported that the modality was used systematically and comprehensive in SFL perspectives to create a realisation of modality in Chinese. The above reviews show that while research has been carried out on various aspects of professional discourse, hardly any research has encompassed all three dimensions of Mood and Modality,

\section{Theoretical Framework-Mood and Modality}

Mood and Modality play an important role in the present study which focuses on interaction in professional discourse in job interviews. Tables 1,2,3,4 and 5 below show the use of Mood, Relation of Mood Structure and Mood Type Modality, Modal Finites, Mood Adjuncts and Metaphors of Modality resources. Halliday (2004) note that from the interpersonal perspective, a clause belongs to the system of Mood and is analysed into components of Mood and Residue as shown in Table 1 below. 
Table 1 :Mood

\begin{tabular}{|c|c|c|}
\hline Subject & Finite & \\
\hline We & Have & two choices \\
\hline \multicolumn{2}{|c|}{ Mood } & Residue \\
\hline
\end{tabular}

Source: Halliday (2004),An Introduction To Functional Grammar(3rd Edition). Great Britain:Arnold.pp.57-73)

The Moodsystem is constituted in a sentence by the Subject and Finite is recognised to be a part of the clause that enables negotiation of meanings to go on between language users. There are basically three main types of mood in English, the Declarative (which realises a statement), Interrogative (which realises a question) and Imperative (which realises command) (Halliday,2004), see Figure 1.

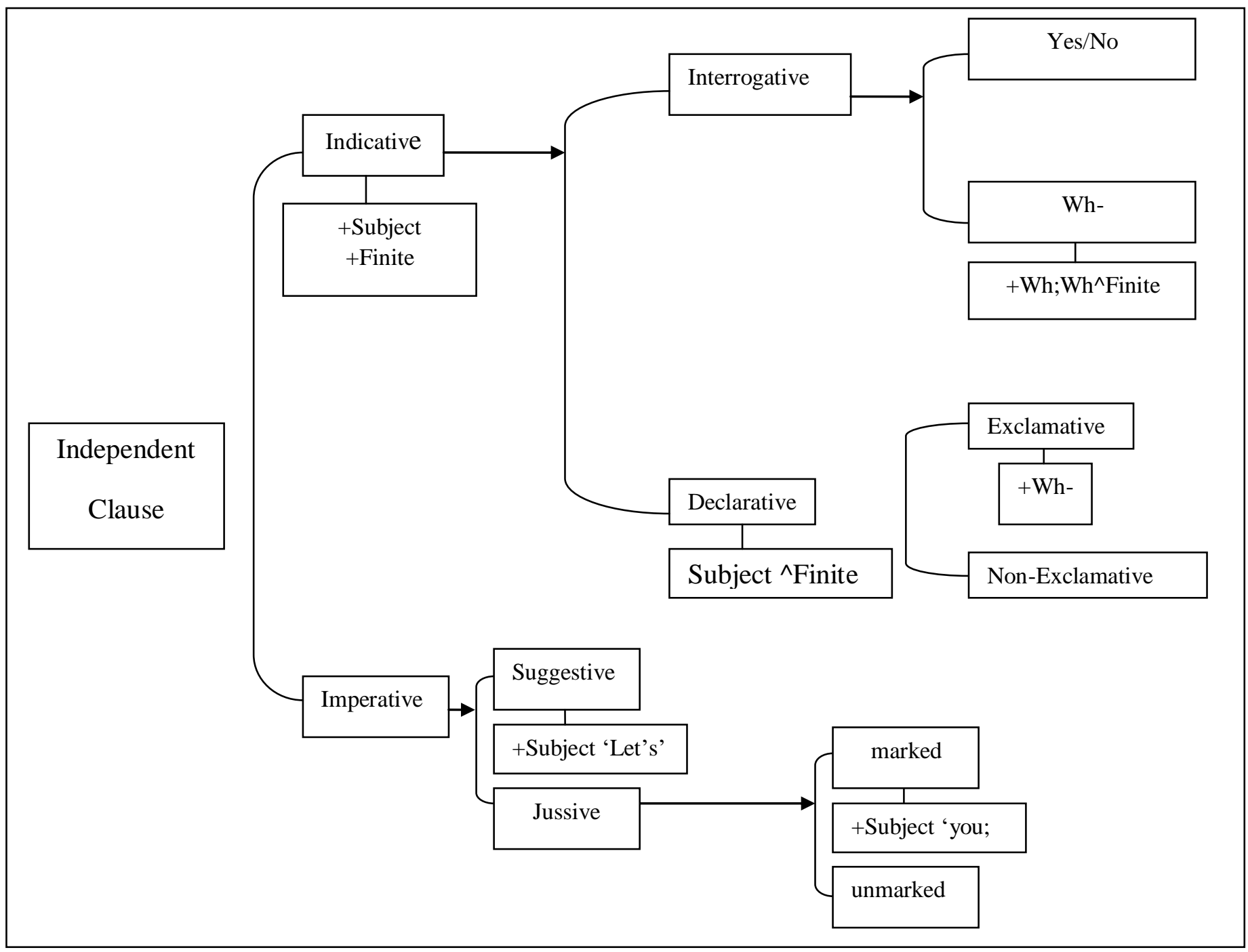

Figure 3.2. The Mood System

(Source: Halliday \& Matthiessen, 2004,An Introduction to Functional Grammar(3rd Edition). Great Britain:Arnold.p.57)

Figure 1: $\quad$ The Mood System (Source: Halliday, 2004) 
The three types of moods are distinguished according to the structure of their Mood Block or Mood element.The different types of Modality and their sub-categories are shown in Table 2.

Table 2 : Modality

\begin{tabular}{ll} 
Modality & \\
\hline Modulation (Commands and Offers) & Modalisation (statements and questions) \\
Expressing degrees of & Expressing degrees of \\
$\begin{array}{ll}\text { 1. obligation } & \text { 1. probability and } \\
\text { 2. inclination/readiness } & \text { 2. usuality }\end{array}$
\end{tabular}

Source: Halliday (2004)

Halliday, (2004) stated that Modality can be expressed through modal finites and mood adjuncts. Modality that denotes mode or manner refers to how speakers demonstrate their actions and take up a position, express an opinion or point of view or make a judgment. In order to do this, speakers may take a strong or a weak stand in relation to the statements and questions (modalisation) and offers and commands (modulation) they make.Table 3 explains that the use of modal finites in low modality, must/mustn't in high modality, would/wouldn't in a median modality, and lastly might/may indicating probability.

Table 3 :Modal Finites

\begin{tabular}{lll}
\hline Low & Median & High \\
\hline Can, may, could, might & $\begin{array}{l}\text { Will, would, should, is to, } \\
\text { was to }\end{array}$ & $\begin{array}{l}\text { Must, ought to, need, has to, } \\
\text { had to }\end{array}$ \\
Needn't, doesn't didn't & Won't, wouldn't, shouldn't & $\begin{array}{l}\text { Mustn't, oughtn't to, can't } \\
\text { couldn't }\end{array}$
\end{tabular}

Source: Halliday (1994)

The examples above explain the modal finite in the accurate form and these may take into negative form, i.e. can't. The degree of the actions to be taken or carried out depends on the degree of command words (modal finites) used. Table 4 refers to the patterns of Mood Adjuncts which are closely associated with the meanings construed by the Mood, Modality and also intensity. 
Table 4 : Mood adjuncts of Modality

\begin{tabular}{ll} 
Type & Example \\
\hline Probability & Probably, possibly, certainly, perhaps, maybe \\
Usuality & Usually, sometimes, always, never, seldom, rarely ever \\
Readiness & Willingly, readily, gladly, certainly, easily \\
Obligation & Definitely, absolutely, possibly, at all cost, by all means \\
Time & Yes, still, already, once, soon, just \\
Typicality & Occasionally, generally, regularly, mainly, for the most part \\
Obviousness & Of course, surely, obviously, clearly \\
Intensity & Just, simply, merely, only, even, actually, really, in fact \\
Degree & $\begin{array}{l}\text { Quite, almost, nearly, scarcely, hardly, absolutely, totally, } \\
\text { utterly, entirely, completely }\end{array}$
\end{tabular}

Source: Halliday, 1994,An Introduction to Functional Grammar. London: Edward Arnold. p.57) It is also the expression of the speaker's attitude towards what he / she is saying and the speaker gets into the text expressing a judgment about the certainty, likelihood, or frequency of something happening or being. Both modal and mood adjuncts can be classified according to the degree of certainty or usuality they express: i.e. low (might, possibly, sometimes), median (may be, probably, usually), high (must, certainly, always).This explains the role of interpersonal meanings as it will help the interviewer to get an understanding of the thought process of the interview.

Modality can also be expressed metaphorically using a projection sequence (a pair of projecting and projected clauses) for example, refer Table 5.

Table 5: Metaphors of Modality

$$
\text { I guess I can visit you next month. }
$$

I think I can do it next week.

I'm sure the pupils will pass the exam.

Source: Halliday (1994)

In the above examples, the source of modality is made explicit and the speaker himself is recognised to be the one who is responsible for the modal assessment.

\section{Methodology}

This is a qualitative study (Creswell, 2018) on interaction in professional discourse in job interviews. The data collected was from one of the organisation in Malaysia which dealt with customer services. The interviews were divided into morning and afternoon sessions. Pseudonyms were used to label the candidates from No.1-10. An approval letter was issued by the company and participants were asked to give their consent for this study. Ten candidates were selected as participants for this study. They were selected at the interview sessions after undergoing a few stages designated by the company itself. There were five 
interview sessions and the audio-taping lasted for about nine hours; each candidate took about 25 to 35 minutes. All the audio data were transcribed and converted into digital format. The transcribed data was numbered by the researcher accordingly. Participant Observation method was used in this study as the interviewers involved were the observers. The collected data were analysed based on Halliday's Mood and Modality (1994) summarised in Droga and Humphrey's (2002) theory .

\begin{tabular}{|c|c|c|c|c|c|c|c|c|c|c|c|c|c|c|}
\hline Participa & Low & & & & Med & $a n$ & & & & High & & & & \\
\hline & Can & $\begin{array}{l}\text { Ma } \\
y\end{array}$ & $\begin{array}{l}\text { Coul } \\
\text { d }\end{array}$ & $\begin{array}{l}\text { Migh } \\
t\end{array}$ & $\begin{array}{l}\text { Wil } \\
\text { I }\end{array}$ & $\begin{array}{l}\text { Wo } \\
\text { uld }\end{array}$ & $\begin{array}{l}\text { Shou } \\
\text { Id }\end{array}$ & $\begin{array}{l}\text { is } \\
t \\
0\end{array}$ & $\begin{array}{l}\text { wa } \\
\text { s } \\
\text { to }\end{array}$ & $\begin{array}{l}\mathrm{Mu} \\
\text { st }\end{array}$ & $\begin{array}{l}\text { oug } \\
\text { ht } \\
\text { to }\end{array}$ & $\begin{array}{l}\text { need } \\
\text { to }\end{array}$ & $\begin{array}{l}\text { has } \\
\text { to }\end{array}$ & $\begin{array}{l}\text { Had } \\
\text { to }\end{array}$ \\
\hline $\begin{array}{l}\text { Candidate } \\
1\end{array}$ & $\begin{array}{r}1+ \\
1-\end{array}$ & & & & & & & & & & & & & \\
\hline $\begin{array}{l}\text { Candidate } \\
2\end{array}$ & $8 x$ & 1 & & 1 & $3 x$ & & & & & & & & & \\
\hline $\begin{array}{l}\text { Candidate } \\
3\end{array}$ & 1 & & 1 & & $7 x$ & $3 x$ & & & & & & & & \\
\hline $\begin{array}{l}\text { Candidate } \\
4\end{array}$ & & & & & $6 x$ & & & & & & & & & \\
\hline $\begin{array}{l}\text { Candidate } \\
5\end{array}$ & & & & & $3 x$ & $6 x$ & $2 x$ & & & & & & & \\
\hline $\begin{array}{l}\text { Candidate } \\
6\end{array}$ & $2 x$ & 1 & 1 & 1 & $2 x$ & $3 x$ & 1 & & & 1 & & & & \\
\hline $\begin{array}{l}\text { Candidate } \\
7\end{array}$ & $\begin{array}{l}3 x \\
1-\end{array}$ & & & & 1 & 1 & & & & & & & & \\
\hline $\begin{array}{l}\text { Candidate } \\
8\end{array}$ & 1 & & & & 1 & $2 x$ & & & & & & & & \\
\hline $\begin{array}{l}\text { Candidate } \\
9\end{array}$ & $2 x$ & & & 1 & $3 x$ & & 1 & & & 1 & & & & \\
\hline $\begin{array}{l}\text { Candidate } \\
10\end{array}$ & $3 x$ & & & & $2 x$ & $4 x$ & & & & & & & & \\
\hline Total & 23 & 1 & 2 & 3 & 28 & 15 & 5 & 0 & 0 & 2 & 0 & 0 & 0 & 0 \\
\hline Total (\%) & $\begin{array}{l}28 \\
\%\end{array}$ & $\begin{array}{l}1.3 \\
\%\end{array}$ & $3 \%$ & $4 \%$ & $\begin{array}{l}35 \\
\%\end{array}$ & $21 \%$ & $6.3 \%$ & 0 & 0 & $3 \%$ & $0 \%$ & $0 \%$ & $0 \%$ & $0 \%$ \\
\hline
\end{tabular}

Findings

The findings of the current study consist of Mood and Modality (Halliday, 1994),

Mood and Modality

Table $\mathbf{6}$ :Choices of Modal Finites by the Interviewees

Note: These may also take a negative form eg. Can't 
The Mood shows grammatical variation through the Subject and the Finite (See Table 1Mood). Modality is also located in the mood (See Table 2-Modality). This study did not analyse the elements in the Residue any further than Mood Block as the researcher looks into candidates' conversation, not the interviewers.

Table 6 shows the choices of modal finites used by the interview candidates. Candidate 1 (C1) had used the low modal finite 'can' once and the modal 'can' $t$ ' once. $C 1$ did not use any of the median or high modal finites. Candidate 2 (C2) had used 'can' 9 times, 'may', and 'might' once respectively, and 'will' 3 times compared to Candidate 3 (C3) who had only used 'can' and 'could' once respectively, but 'will' 7 times and 'would' 3 times. Candidate (C4) had used 'will' 6 times and did not use any of the other modal finite.

However, Candidate 5 (C5) had used 'will' 3 times and 'would' 6 times, and also 'should' twice. Next, Candidate 6 (C6) had managed to use most of the modal finites by using 'can' and 'will' twice, 'may', 'could', 'might', 'should' and 'must' one time respectively. 'Would' was used by C6 3 times. Candidate 7 (C7) had used 'can' 3 times and 'can't' once compared to 'will' and 'would' which were used once each. Candidate 8 (C8) had also used 'can' and 'will' once, but 'would' twice. Lastly, candidate 9 (C9) had used 'can' twice and 'will' 3 times respectively, and 'might', 'should', and 'must' were also used once each. Candidate (C10) used 'can' 3 times, 'will' 2 times and 'would' 4 times.

\title{
Modal Finites
}

\section{Low-Modal Finites}

Based on the table 4.1 the choices of modal finites were divided into three groups such as low, median and high. The analysis showed that candidate 2(C2) had used 'can' 7 times compared to other candidates. 'Can' is a modal finite that expresses Low Modality. It was also found that C2 had used 'can' consistently throughout the conversation. This was demonstrated by the questions asked by the interviewer. Low modal finites examined how much responsibility of the speaker was accepted for the expression of C2' opinions, (See excerpt C2).

\section{Excerpt -Candidate 2}

\author{
Interviewer What do we do? \\ Candidate As I understand ... this monitors the advert on we can look at \\ every empty slot... \\ Interviewer What is your long term objective? \\ Candidate My long term objective is I can get my own house \\ Interviewer That's personal...your long term career objective? \\ Candidate I can put myself in a good company... \\ Interviewer Planning to stay with us for 10 years? Are you serious? \\ Candidate If this is suitable for me and the company can give... \\ Interviewer In your life experience, your experience aa... How far can a \\ person go in customer service industry? \\ Candidate My experience for customer service for example, they only \\ can... \\ Interviewer But you do keep contact with people. Do you think you can? \\ Candidate Can because I still do something like listening. It might be \\ boring but can manage to handle the pressure.
}




\section{Median-Modal Finites}

From the analysis, it was found that candidate (C3) had used 'will' 28 times in job interviews.C3 used 'will'to express modal finite that might take any action that was needed to ensure the customers felt comfortable. C3 also made sure that C3 controlled the situation. This indicated C3 approached the situation professionally, (See excerpt candidate 3).

\section{Excerpt-Candidate 3}

\begin{tabular}{|c|c|}
\hline Interviewer & I see. And how do you deal with difficult customers? \\
\hline Candidate & $\begin{array}{l}\text { Of course I will follow. Other than that, I will try to find out the } \\
\text { useful solution to solve the customer's needs. }\end{array}$ \\
\hline Interviewer & Well, how do you handle complaints? \\
\hline Candidate & $\begin{array}{l}\text { I will accept the customer's complaints with a positive ways } \\
\text { and try to solve it. Otherwise, I will not give any idea } \\
\text { of the results. }\end{array}$ \\
\hline Interviewer & $\begin{array}{l}\text { Can you explain how is your contact communication your } \\
\text { customers? }\end{array}$ \\
\hline Candidate & $\begin{array}{l}\text { Ahh... I will always inform the news to my customer whenour } \\
\text { company roll out the new product or service. Otherwise, I will } \\
\text { get the... }\end{array}$ \\
\hline Interviewer & $\begin{array}{l}\text { Wee, and please give me a few reasons why should we should } \\
\text { hire you? }\end{array}$ \\
\hline Candidate & Ehh..because... \\
\hline iterviewe & Ahh... I think your company wi \\
\hline
\end{tabular}

\section{High Modal Finites}

From the analysis it was found that only candidates 6(C6) and 9(C9) had used 'must' in the interview. 'Must'was used twice in the interview to express high modality. This was demonstrated by the questions asked by the interviewer that had given both candidates clues that it was compulsory for any customer service officer to work with perfect timing(See excerpts Candidate 6 \& 9).

\section{Excerpt-Candidate 6}

Interviewer Okay nice! Now let say you are customer service in the office, what you must do?

Candidate I must pick up the call, and answering with the clearest words like "Hello, good morning! May I know with whom I speak and what I can help you?"

\section{Excerpt-Candidate 9}

Interviewer Well, what would you do if your customers said that handle their problems slowly?

Candidate $h m m$.... in that case, I must search some information an always hear some opinion from senior in order to faster my ability in work. 


\section{Mood Adjuncts}

Table 7: Choice of Mood Adjuncts among the Interviewees

Table 7 shows that the use of Mood Adjuncts of interviewees in the job interview. The most

\begin{tabular}{|c|c|c|c|c|c|c|c|c|c|}
\hline $\begin{array}{l}\text { Participan } \\
\text { ts }\end{array}$ & $\begin{array}{l}\text { Probabil } \\
\text { ity }\end{array}$ & $\begin{array}{l}\text { Usuali } \\
\text { ty }\end{array}$ & $\begin{array}{l}\text { Readin } \\
\text { ess }\end{array}$ & $\begin{array}{l}\text { Obligati } \\
\text { on }\end{array}$ & Time & $\begin{array}{l}\text { Typicall } \\
y\end{array}$ & $\begin{array}{l}\text { Obvious } \\
\text { ness }\end{array}$ & $\begin{array}{l}\text { Intensi } \\
\text { ty }\end{array}$ & Degree \\
\hline Candidate & & & Certainl & & & & & Actuall & \\
\hline 1 & & & y & & & & & & \\
\hline Candidate & Maybe & Seldo & & & & & & Actuall & \\
\hline 2 & $2 x$ & $\mathrm{~m}$ & & & & & & $y$ & \\
\hline Candidate & Certainl & Usuall & & & Once & & & Actuall & Almost \\
\hline 3 & y & $\begin{array}{l}y \\
\text { Always } \\
2 x\end{array}$ & & & $\begin{array}{l}\text { Already } \\
2 x\end{array}$ & & & y $2 x$ & $\begin{array}{l}2 \mathrm{x} \\
\text { Complet } \\
\text { ely }\end{array}$ \\
\hline $\begin{array}{l}\text { Candidate } \\
4\end{array}$ & & & & & & & & & \\
\hline Candidate & & Usuall & & & Already & & Obviousl & Actuall & \\
\hline 5 & & $\begin{array}{l}\text { y } 2 x \\
\text { Always }\end{array}$ & & & $5 x$ & & y & $\begin{array}{l}\text { y } \\
\text { Really }\end{array}$ & \\
\hline $\begin{array}{l}\text { Candidate } \\
6\end{array}$ & Maybe & & & & Already & & $\begin{array}{l}\text { Of } \\
\text { course } \\
\text { Obviousl } \\
y\end{array}$ & & $\begin{array}{l}\text { Complet } \\
\text { ely }\end{array}$ \\
\hline $\begin{array}{l}\text { Candidate } \\
7\end{array}$ & & $\begin{array}{l}\text { Usuall } \\
\text { y } 2 x\end{array}$ & & & & & & & \\
\hline Candidate & & & Certainl & Definitel & & & & & \\
\hline 8 & & & & y & & & & & \\
\hline Candidate & Probabl & Usuall & Certainl & & & & & & \\
\hline 9 & $\begin{array}{l}\text { y } \\
\text { Maybe }\end{array}$ & $\begin{array}{l}\text { y } \\
\text { Always }\end{array}$ & y & & & & & & \\
\hline $\begin{array}{l}\text { Candidate } \\
10\end{array}$ & & & & & & & & & \\
\hline Total & 6 & 16 & 3 & 1 & 9 & 0 & 3 & 6 & 5 \\
\hline Total (\%) & $16 \%$ & $33 \%$ & $6 \%$ & $2.0 \%$ & $19 \%$ & $0 \%$ & $6 \%$ & $16 \%$ & $10 \%$ \\
\hline
\end{tabular}

used feature was 'usuality' ( $n=16,33 \%)$ by the interview candidates. This was followed by 'time' ( $n=9 ; 19 \%)$, 'probability' ( $n=6 ; 16 \%)$, 'intensity' ( $n=6 ; 16 \%)$, 'degree' $(n=5 ; 10 \%)$, 'readiness' ( $n=3 ; 6 \%)$ and 'obviousness' ( $n=3 ; 6 \%)$. The least feature was 'obligation' $(n=1 ; 2.0 \%)$. As shown in table 7 the most used features were 'usuality'and 'time'. The least used mood adjuncts among the candidates were obligation, readiness, obviousness and degree. From this it was obvious, most of the candidates had used 'usuality' followed by 'time' in the interview conversation, which emphasise the regular activities from the speaker's mind and 'already' indicates time until now. Here, candidate 5 relates to the time itself, which may be near, future or past relative to the speaker-not to an expectation. (See excerpt candidate 7 \& 5). 


\section{Excerpt-Candidate 7}

Interviewer Have you had any difficulties with your manager?

Candidate I can't recall, usually it happens but will solve quickly rather than prolong the issues.

Interviewer Would you be able to work extended hours as necessary toperform the job?

Candidate I'm accustomed to working long hours during the week. I usually work...

\section{Excerpt-Candidate 5}

Interviewer Ok, I see, well how do you manage your time every day?

Candidate Emm...usually every morning when I wake up. I have already...

Interviewer Well, that's great; actually there are so many companies in this area, why would you like to choose our company?

Candidate Ehhh... before I choose this company I have Already company has already had more.

Interviewer Aaaah...ok, could you please give two reasons why should I hire you?

Candidate Well...obviously, first I have the qualification which is your company is needed and the second is since I have read about your company, I have already....

Interviewer Ok... One last question, how much salary do you expected?

Candidate Hmmmm... Since I already have two years working experience, I expect that my salary will not less than RM 3000.00 


\section{Metaphors of Modality}

Table 8: The use of Metaphors of Modality among the Interviewees

Table 8 shows the most used feature was 'I think' $(n=9 ; 90 \%)$ and the least used feature was ' guess' ( $n=1 ; 10 \%)$. The excerpts can be seen below.

As shown in Table 8 Candidate (C3) said 'I think' three times during the interview

\begin{tabular}{|l|l|}
\hline Participants & Metaphorical Realisation \\
\hline Candidate 1 & $\begin{array}{l}\text { I guess Projecting mental clause (subjective) } \\
\text { I think Projecting mental clause (subjective) }\end{array}$ \\
\hline Candidate 2 & \\
\hline Candidate 3 & I think Projecting mental clause (subjective) 3x \\
\hline Candidate 4 & I think Projecting mental clause (subjective) \\
\hline Candidate 5 & \\
\hline Candidate 6 & \\
\hline Candidate 7 & I think Projecting mental clause (subjective) \\
\hline Candidate 8 & I think Projecting mental clause (subjective) 2x \\
\hline Candidate 9 & I think Projecting mental clause (subjective) \\
\hline Candidate 10 & I think 9x I guess 1x \\
\hline Total & I think -90\% I guess-10\% \\
\hline Total (\%) \\
\hline Note :Total Candidate occurrences x 100 \\
\hline \multicolumn{1}{|c|}{ Grand Total Occurrences } \\
\hline
\end{tabular}

session compared to other candidates for the questions asked by the interviewer. The first ' think' was used to show emphasis that C3 had the question before. The second 'I think' was used in a different tone to the previous situation. At the end of the interview C3 stated that 'I think' that was all for my question. Overall, the above excerpts showed that the candidates' answers were convincing but lacked assurances. Halliday (1994) and Martin (1997) say that 'I think' can be uttered in different situations as it was projecting a mental clause subjectively where the opinion of the speaker was not expressed in the common.To sum up, not all of the Mood and Modality resources were used in the job interview. Although the candidates were able to use the Mood and Modality resources their general low proficiency in English hindered the meaning they tried convey .

\section{Discussion}

Interviewers are constantly looking for candidates who are able to express themselves and show their expertise. The selection of candidates by the Human Resource Department is important for the company. Usually, candidates try to show their planning and manageable skills as well as intellectual abilities to work in a company.

The findings of this study show that most of the candidates who attended the interviews were not able to use Mood and Modality resources appropriately because there were many resources available, so they repeatedly used the Modal Finites, 'can' and 'will' as in everyday conversations. It is also worth stressing that the candidates did not possess sufficient command of the English Language to carry out the conversation professionally or to make the conversation interesting. 
Nonetheless, the interviewees still made salient attempts to use the English language, although their proficiency level was considerably weak. On the other hand, there were some candidates whose command of the English language was good, but they had difficulty in delivering the message. One example was C9, who used Mood and Modality resources in a sensible way She was not able to demonstrate her ability in terms of job skills because she did not have sufficient experience and knowledge about the scope of the job.

Based on the analysis of Mood and Modality, it was found that the features 'can' and 'will' were used most often by the interviewees, and the features 'may,' 'could,' 'might,' 'would' and 'should' were the least used. The features not used at all were 'is to,' 'were to,' 'ought to,' 'need to,' 'has to' and 'had to'. The candidates who used Modal Finites the most were $\mathrm{C} 2, \mathrm{C} 3$ and C6. Using Modal Finites helped them achieve a better interaction with the interviewers.This reflects the candidates' inadequate proficiency in the English language, even though they tried. There were others like C9 who was good at English and had the ability to use Mood and Modality resources, but had inadequate knowledge of the scope of the job. Therefore, the candidate's use of Mood and Modality were logical and accurate alhough she may not have performed very well in terms of content at the interview.

Most of the candidates who did not have sufficient knowledge of Mood and Modality also had difficulties in using appropriate words during the interview. This is because the candidates had poor background of English and found mastering grammar difficult. In general, the finding is related to $\mathrm{C} 2, \mathrm{C} 3$ and $\mathrm{C} 6$ confirms the finding from the study conducted by Depraetere and Reed (2006). In their study, candidates were asked questions like "Can you climb over that wall?" or "Is it possible for you to climb over that wall?" These kinds of statements use Mood and Modality in the interview to determine the truth of the answers and polysemy.

In the working world, job interviews play a vital role, not only for fresh graduates, but also those who intend to enhance their careers, pursue promotions and pass entry requirements. They all have to go through an interview process at some time or other. Therefore, the success of the interview will depend on the ability to discover the needs of the organisation and empathize with the interviewer. One way of achieving this is by using Mood and Modality resources. Strong language skills are absolutely required to survive and succeed in today's business world. In general, the above finding is agreed by the study by the study of Syamsidar, Ika and Dian (2019) that the use of interpersonal meanings; Mood and Modality demonstrated ones language ability in any professional contentext as in job interviews.

\section{Implication of The Study}

Interaction in a job interview involves the use of Mood and Modality resources. The findings have important implications in challenging candidates to provide significant information to interviewers. They should also be able to have the appropriate professional interaction and get the interviewers engaged in the conversation. The evidence from this study show that some of the candidates were very confident as they knew how to express themselves in an accurate and precise manner.

However, the majority seemed to have lost their confidence as they lacked the necessary language proficiency skills. This thought was echoed by one of officers from the banking organisation who suggested that the lack of self-assurance among job seekers was that they had too much anxiety and sothey could not speak confidently (Nadiah , 2011). The offficer further added that, many candidates did not prepare themselves before going for interviews. It appeared $c$ that candidates attended the interviews without a basic knowledge 
about the potential employers and they had to bear the consequence of creating a bad first impression during the interview.

The result of this study indicated that candidates also need to learn to ask questions at the end of the interviews. In the case of the current study, the candidates, who asked questions, attempted to show that they were interested in getting the job and were preparing themselves for work. This, in return, convinced the interviewer of their communication skills and abilities. The Interviewers also got the impression that the candidates were interested in the job. Using Mood and Modality features enhanced their speaking abilities and also language skills especially at the interview.

The lack of English language proficiency among new graduates is the biggest problem at this time and age (Hisham, 2011). Unlike graduates of the past, current graduates are able to access knowledge easily with the advent of tablets, iPhones, and other sophisticated electronic devices; however, they are still lacking in terms of Communication Skills. This is achieved by using convincing expressions and showing their willingness in taking on assigned tasks. Nowadays, candidates who attend interview can easily access the Internet and get information about companies. This shows the employers that the respective candidates are well-prepared to work for the organisations.

An issue that was not addressed in this study was the selection of the candidates for the job. The researcher wanted to know, after the interviewing session, who the candidates were selected for the job. Unfortunately, the organisation was not permitted to reveal such information.Job interviews require the candidates to be able to sell their expertise in order to impress the interviewer through professional discourse. The research objectives and questions focused on Mood and Modality that is being used in some job interviews. Mood and Modality gives clues of the strentghs and weaknesses of the Malaysian fresh graduates in terms of what is expected in the job market. .

\section{Conclusion}

In today's era of globalisation, there is a greater demand for specialisation in various fields, thus bringing tremendous transformation around the world, including Malaysia. This, in return, has led to various investigations conducted by researchers; particularly those who are involved in the field of Modern Language and Applied Linguistics. One of the main research aspects which has caught the attention of many researchers is professional discourse. This study was conducted to analyse professional discourse among related speakers, which related to a type of communication that was carried out by professionals (Parodi, 2010).

Job interviews require the candidates to be able to sell their expertise in order to impress the interviewer through professional discourse which focused on Mood and. The findings of the current study provided some clues of the strengths and weaknesses of a small selection of Malaysian graduates in their attempts to get a job.

Interview candidates must show the importance of using appropriate information with selfconfidence. They should create a positive impression and be able to converse convincingly during the interview. At same time they should also use good English by using appropriate Mood and Modality resources to express their strengths and expertise. In the Malaysian context, such features are used by those proficient in the language. Even in a typical conversation these features are used to show ability, willingness, probability, and so on. It is advisable that those not proficient must go through a few preparatory courses and trainings to enhance their grammar knowledge. They help candidates to focus on themselves, as they will manage to focus the interviewers' attention to themselves. 
Companies should seriously look into interviews to maintain their reputation and to avoid a negative impression. This is because an interview is a meeting between a candidate for employment and an organisational representative to decide whether the candidate is qualified for the job and work for the company whose aim is to develop professional workers. Doyle $(2012$, p.18) rightly says "neglecting professional discourse simply means that the company is neglecting its own pride and honour", Hence, neglecting an interview simply means the company is neglecting its own future.

If the debate is to be moved forward, a better understanding of this field of study needs to be developed. It is hoped that further research can be carried out on linguistic expressions such as variations of vocabulary, expansion of sentences, correct use of tense and structure and word choices of the interviewer as well as the interviewee in professional interaction. A comparison study is also needed to determine the English language use of successful and unsuccessful candidates. This comparison study will help in the training and communication of those still in the schools, colleges and universities. Further research may also be conducted on the interviewers themselves. This would be helpful for organisations to evaluate the interviewer's performance during the interviews. Using appropriate words during interviews is also applicable for the interviewers and not only interviewees.

\section{Acknowledgement}

I would like to thank my supervisor, Dr. Sridevi Srinivass, for her guidance and patience during the period of supervising my thesis work from September 2012-December 2014. Without her advice and help, this study would never have been completed. The credit should be given to her for the sacrifices and valuable time which she spent for this work. I should mention this, after my proposal defence in March 2013, she was hospitalised. After recovering she immediately read my chapters and gave her valuable inputs to rectify my chapters. I am truly grateful to her and if you ask me, she is one unforgettable person in my life. May God bless her with all the best in her future undertakings and her divine life.

\section{References}

Abu Bakar, A. (2020). English barrier for Bumiputera graduates in job hunt. Retrieved January 15, 2021, from

https://www.freemalaysiatoday.com/category/nation/2020/09/20/english-barrierfor-bumiputera-graduates-in-job-hunt-says-mef/

Ahmed, \& Farouk, D. A. (2008). How to improve the employability of graduates. Business Intelligence Journal, 2(2), 288-312.

Al-Atabi, M. (2019). Ensuring graduates have soft skills. The Star. Retrieved January 15, 2021, from https://www.thestar.com.my/news/education/2019/01/20/ensuring-graduateshave-soft-skills/

Bhatia, V. J. (2004). Access a Profession: Professional Knowledge or Academic Knowledge In A Particular Field.(p.22).

Brown \& Levinson. (1978).Politeness:Some universals in language usage.Cambridge: Cambridge University Press

Chau, C. (2021). Malaysian fresh grads urged to gain new skills to boost employability. Hrmasia. Retrieved September 24, 2021, from https://hrmasia.com/malaysianfresh-grads-urged-to-gain-new-skills-to-boost-employability/

Cai-yan, F. (2011). Functions of metaphors of modality in president's radio addresses. 9(11,700-707), Retrieved 04 December, 2021, from 
http://connection.ebscohost.com/c/articles/70274053/functions-metaphorsmodality-presidents-radio-addresses

David, W. (2009). Malaysia's english language crisis. New Strait Times. Retrieved 03 December, 2021, from http://www.nationmultimedia.com/national/Malaysias-Englishlanguage-crisis-30218090.html.

Doyle, A. (2012). What is Interview? Job searching: New York Terms Company.

Retrieved from http://jobsearch.about.com/od/interviewsnetworking/f/what-is-aninterview.htm(p.11).

Diah, S., Martin, L. M., Noer, J. S., \& Mustafa, M.(2020).Mood and modality analyses in investigating ideology of news about Indonesia in bbc world webnews, Journal on Interdisciplinary Studies in Humanities, 3(3), 408-414.

Droga, L., \& Humphrey, H. (2002). Getting Started with Functional Grammar. Australia: Target Texts (p.117).

Depraetere, I., \& Reed, S. (2006). Mood and Modality in English. The handbook of English linguistics, Australia, Sydney : Springer-Verlag.

Eggins, S. (2004). An Introduction to Systemic Functional Linguistics. Great Britain: Continuum (p. 20).

Goodwin, C. (2004). Professional vision, Applied Linguistics, UCLA, Retrieved from http://www.sscnet.ucla.edu/clic/cgoodwin/94prof_vis.pdf.(pp.12)

Halliday, M. A. K. (1994). An Introduction to Functional Grammar. London: Edward Arnold.(pp.77-126).

Halliday, M. A. K. (1985). Systemic Background. In "Systemic Perspectives on Discourse,1: Selected Theoretical Papers" from the Ninth International Systemic Workshop, Benson and Greaves (eds); . 3 in The Collected Works, (pp.121).

Holmes, J. (2009). Discourse in the workplace literature review. School of Linguistics and Applied Language Studies, Retrieved 01 December 2021, from http://www.victoria.ac.nz/lals/centres-and-institutes/language-in-theworkplace/docs/ops/OP-12.pdf.(pp.12).

Jensen, K. (2007). A construction-based study of English predicators mood and modality, Journal of Modern Language, 5(2), 9-23.

Jian, X. (2009). Interpreting metaphor of modality in advertising English. 2(4), Retrieved 10 December 202, from http://www.ccsenet.org/journal/index.php/elt/article/view/4459/0.

Kenayathulla, H. B., Ahmad, N. A., \& Idris, A. R. (2019). Gaps between competence and importance of employability skills: Evidence from Malaysia. Higher Education Evaluation and Development, 13(2) 97-112.

Nezhad, P. M. R., \& Tavakoli, F. H. (2013).The surveying of the polarity by mood adjuncts in persian language based on functional grammar approach, 9(32).

Martin, J. R. (2001). Language, register and genre. In Burns, A \& Coffin, C (eds), Analysing English in a global context. London: Routledge.(p.57).

Nezhad, P. M. R., \& Tavakoli, F. H. (2013).The surveying of the polarity by mood adjuncts in persian language based on functional grammar approach,9(32).

Olga, D. N. (2009). Interpersonal meanings in the genre of diplomatic addresses. Journal of Modern Language, 2(3), 11-18.

Perdana. E., \& Saragih.A. (2009). Interpersonal metaphor in mata najwa's talk show. Retrieved 10 December, 2021, from

http://jurnal.unimed.ac.id/2012/index.php/jalu/article/download/711/522. 
Parodi, G. (2010). Academic and professional discourse genres in spanish.

Pauw, K. M. O. (2006). Graduate Unemployment in Malaysia.

Ruijuan. (2010). The interpersonal metafunction analysis of barack obama's victory speech. 3(2), Retrieved 02 December, 2021, from http://www.ccsenet.org/journal/index.php/elt/article/view/6258/0.

Sarangi, S. (2010) Motivational relevancies: some methodological reflections on sociolinguistic practice. Sociolinguistics and Social Theory 350-388. London: Pearson.(pp.17 \& 30).

Schryer, C. F., \& Spoel. (2005). Genre theory, healthcare discourse and professional identify formation. Journal of Business and Technical Communication,19(3), 249).

Shayegh, K. (2012). Modality in political discourses of Barak Obama and Martin Luther

King. Science Road Publishing Corporation, Retrieved 10 December, 2021, from http://sciroad.com/TASE/TASE1231/TASE-

Swales, J. M. (1990).English in academic and research settings. Cambridge: Cambridge University Press.

Syamsidar, S., Ika, Y., Dian. N. (2019). Mood And Modality in Soekarno's 1955 Speech. Journal of Language and Literary studies, 2(2), 109-120.

Tan, S. M. (2010). A Systemic Functional Analysis of the Interpersonal Metaphor in Camputer Science Text. (Unpublished master's thesis) University of Malaya, Kuala Lumpur.

Vazquez, I. V., \& Diana, G.(2008). Beyond mood and modality: Epistemic modality markers as hedges in research articles. A cross-disciplinary study.21.

Wai, C. W. (2011). A handicap we must overcome. The Star. Retrieved 01 December, 2021, from

http://www.thestar.com.my/story.aspx?file=/2011/3/13/focus/8256915\&sec=focus.

Wong, N. L. (2009). The interpersonal aspect of help-seeking and help-providing text: $A$ systemic functional investigation into mood and modality. (Unpublished master's thesis), University of Malaya, Kuala Lumpur.

Yang S. (2021). A systemic functional study of the system of modality in Chinese. Sage Publication, 3(3), 1-16. 